\title{
Seasonal Variation in the Population of Indian Black Ibis Pseudibis papillosa, Inhabiting the Arid Zone of Rajasthan, India
}

\author{
K.C. Soni ${ }^{1 *}$, A.N. Sharma ${ }^{2}$ and V.C. Soni ${ }^{3}$ \\ ${ }^{I}$ Department of Zoology, Lohia P.G. College, Churu, Rajasthan-331001, India \\ ${ }^{2}$ Principal, Tilak Mahavidyalaya, Bassi, Jaipur, Rajasthan, India \\ ${ }^{3}$ Department of Bioscience, Saurastra University, Rajkot, Gujarat, India \\ "E-mail:kcsibis@yahoo.com
}

Received: 10.05.2009, Accepted: 26.09.2009

\begin{abstract}
The population of Black ibis (Pseudibis papillosa) inhabiting rural and urban area of Churu city, Rajasthan was seasonally determined by the direct count method. The counting of the Black ibis was made at roosting sites of Churu city $\left(28^{\circ} 15^{\prime} \mathrm{N}\right.$ and $74^{\circ} 55^{\prime} \mathrm{E}, 286 \mathrm{msl}$ ) and it's out skirts area of $400 \mathrm{~km}^{2}$. Total 35 roosting sites were identified in the study area of which 19 were located in the urban area and 16 in the rural areas. It was found that number was relatively higher from June to August in 2003, 2004 and 2005. However, the number was highest from June 2004 to August 2004 and lowest from June 2006 to August 2006. The maximum number of adult was noticed in the rainy months of every year. A sharp decline in the juvenile population was observed from January 2004 to April 2004. Maximum 17 juvenile birds were observed in the months of May and June 2004 and October 2005 while the minimum 4 juveniles were observed in January 2005. An average $40.08 \pm 3.62$ and $35.33 \pm 4.61$ in 2003, $42.5 \pm 4.81$ and $43.16 \pm 8.69$ in $2004,42.16 \pm 4.23$ and $38.33 \pm 4.47$ in 2005 and $36.25 \pm 3.81$ and $34.91 \pm 4.52$ in 2006 ibises were recorded in rural and urban areas, respectively. The maximum number of ibis i.e. 101 individuals, occurred in the month of June, 2004. But in general, the population remained more or less constant with seasonal variations involving dispersion during the monsoons and aggregation during the winters. The winter season adversely affects the population of Black ibis in the study area because of the non availability of preferential food, particularly insects.
\end{abstract}

Key words: Seasonal variation, population, Black ibis, arid zone, Rajasthan, India

\section{Introduction}

It is important to know the population size of a species for ecological studies. Counts of birds are used for many purposes in a variety of field studies. Simple presence or absence information suffices to study avian biogeography, but indices of abundance are needed to track the changing mix of species population associated with plant succession.
Still other studies, as of trophic dynamics, require knowledge of population densities.

There are several methods to census the terrestrial birds (Ralf and Scott, 1981; Davis, 1982). However, any census technique is not absolutely perfect for population estimation of diverse avian species, because each census technique has 
K.C. Soni, A.N. Sharma and V.C. Soni / Our Nature (2009) 7: 193-202

advantages and disadvantages (Pyke and Recher, 1984; 1985; Pyke, 1986). Some methods are accurate, some are fast, some are fun and some bird census techniques pose special methodological problems (Bull, 1981; Dawson, 1981). Many factors could influence applicability of census method, such as habitat type, weather condition, time of census, effect of observer, and behaviour of species (Conant et al., 1981; Robbins, 1981; Skirvin, 1981; Verner, 1985; Koen, 1988; Soni, 2008).

Many Indian bird species roost communally (Gadgil and Ali, 1975). Since the Ibis is fairly large size bird, it is easy to count individuals at roost sites when the species aggregates as per its communal roosting habit (Salimkumar, 1982). A tendency of the bird to return in fairly equal numbers from one night to the following at the selected site was noticed during the pilot study. This behaviour was considered in designing the study method to cover all located and identified roost sites monthly to perform a population census, including individuals scattered in the study area. According to Chavda (1988), aggregations of the Ibis are larger and more stable at the roosts than on the feeding grounds. Referring to this method, it is more reliable to carry out a census at roost sites than on the foraging ground, though the Ibis is a flocking feeder.

Ward and Zahavi (1973) reported that the birds which feed together usually roost together. The birds select as their roost sites locations nearest to their feeding sites (Gadgil and Ali, 1975).Hence it was deliberated that for flock feeding Ibis, direct counts obtained at roosts might give a most reliable census result. This method was earlier applied by Davis (1982), Salimkumar (1982), Sykes (1983), Sheshukumar (1984),
Chavda (1988) and Lathigara (1989). In present study, the method was standardized and census was carried out for long period to understand the trends in population fluctuation.

Population of Black ibis is also estimated every year at various aquatic habitats in India and abroad as a part of Asian Waterfowl Census (AWC) conducted by Asian Wetland Bureau (AWB). In the present study, seasonal variations in the populations of the Black ibis were studied. Comparison was made between the population estimated by the direct count method at terrestrial habitats and counts at aquatic habitats. The counting of the Black ibis in and around Churu city of arid zone of Rajasthan was carried out by using various methods as mentioned in material and methods.

\section{Materials and methods}

The study was carried out in and around Churu city, Rajasthan, India covering 400 $\mathrm{Km}^{2}$ area $\left(29^{\circ} \mathrm{N}\right.$ and $75^{\circ} \mathrm{E}$, rainfall $325 \mathrm{~mm}$, altitude $286 \mathrm{msl})$. The study area was surveyed and roost sites located either by following the flocks of Black ibis returning from their feeding grounds to night roost or by listening to their calls from roost sites early in the morning, and by gathering information from the local people. Observations were made with the help of a binocular (Olympus, 10×50) at the distance of about $40 \mathrm{~m}$ from the roosts to avoid interruption of the birds behaviour. All observations were made in clear weather. Data on rainfall, temperature and humidity were collected from the Meteorological Department of Churu to seek any affect inclement weather may have on the population's fluctuation. The population of the Black ibis was decided by using 
K.C. Soni, A.N. Sharma and V.C. Soni / Our Nature (2009) 7: 193-202

counting at roosting site method. Other methods like nest counting method, point counting method and transect counting method were considered improper due to specific size and behaviour of the Black ibis. Based on a pilot study of consecutive 7 days counts of the ibis at the roost sites selected, it was henceforth assumed that the average number of ibis at any one roost remains more or less constant for a period of at least three week. Each census was carried out during first two weeks of the month. It was assumed no radical overlap of individuals among the different roosts in the study area. Numbers of ibis at roosts were counted either during late evenings or early mornings. Evening counts were started about 2 hours before sunset with no birds in roosts, and continued until dark. Morning counts were started before sunrise when all night roosters were present. Each ibis lacking red warts and the prominent yellow iris was considered to be a juvenile bird so it was possible to census the population of young individuals separately from the mature birds (Ali and Ripley, 1983). The numbers of ibis at all active roosts were recorded every month and the total of the roosts was treated as a population.

\section{Results}

Total 35 roost sites were identified in the study area of which 19 were located in the urban area and 16 in the rural area. All of the sites were monitored once a month to record the number of birds at each site. Birds were counted at roosting on khejadi tree during day time. They were also counted at roosting on Neem, Peepal and Bargad trees during night. It was found that number was relatively higher from June to August in 2003, 2004 and 2005 (Table 1). However, the number was highest from
June, 2004 to August, 2004 and lowest from June, 2006 to August, 2006 (Figure 1).

Figure 2 highlight the population trend of juvenile and adult ibis during the study period. The maximum number of adult was noticed in the rainy months of every year. A sharp decline in the juvenile population was observed from January, 2004 to April, 2004. Maximum 17 juvenile birds were observed in the month of May, 2004; June, 2004 and October, 2005 while the minimum 4 juveniles were observed in January, 2005. There was not a single month when we did not find juvenile ibis.

Figure 3 highlight a positive relationship between the size of the ibis population and rainfall during rainy season. The population of the ibis attained maximum average $85.66 \pm 11.53$ during 2004 when the study area received $343 \mathrm{~mm}$ of rain, whereas population was found to lower average of $71.16 \pm 1.52$ in 2006 when the study area received only $223 \mathrm{~mm}$ of rain. In 2005, rainfall was $522 \mathrm{~mm}$ and above the average, but population was $79.66 \pm 5.89$ and noticeably lowers in comparison to previous year 2004 (Table 2). An average of $77.97 \pm 8.74$ ibis were recorded during the study period of 48 months from January, 2003 to December, 2006 with slightly lower number averaging $77.54 \pm 6.00$ during high rainfall in 2003 and 2005 and slightly higher but consistent number averaging $78.41 \pm 10.93$ during low rainfall year of 2004 and 2006.

Table 3 depicts that an average $40.08 \pm 3.62$ and $35.33 \pm 4.61$ ibises in 2003 , $42.5 \pm 4.81$ and $43.16 \pm 8.69$ in 2004, $42.16 \pm 4.23$ and $38.33 \pm 4.47$ in 2005 and $36.25 \pm 3.81$ and $34.91 \pm 4.52$ in 2006 were recorded in rural and urban areas respectively. The bird showed a strong preference for the rural area for roosting in 
K.C. Soni, A.N. Sharma and V.C. Soni / Our Nature (2009) 7: 193-202

2003, 2005 and 2006 while in 2004 bird showed preference for roosting in urban area. However, there was no much great difference in preference for rural and urban area during the study period of 2003 to 2006. An average $40.25 \pm 4.73$ and $37.93 \pm 6.57$ ibis were recorded in rural and urban area respectively during the study period of January, 2003 to December, 2006.

Figure 4 depicts that in overall study period of 48 months from January, 2003 to December, 2006 the bird preferred rural roosting sites in 26 months and urban roosting sites in 21 months and in one month rural and urban preference was same.

The maximum number of ibis i.e. 101 individuals, occurred in the month of June, 2004. But in general, the population remained more or less constant with seasonal variations involving dispersion during the monsoons and aggregation during the winters (Figure 1).

Maximum 17 juvenile birds were found in the month of May, June, 2004 and in October, 2005. The lowest number of juveniles occurred in the month of March, 2003 and January, 2004.

\section{Discussion}

The population of the birds follows fluctuations as per climatic changes, so also the Black ibis. The population count of this bird at roosting sites shows seasonal variation. The number of the bird was more during rainy season and less in winter and summer seasons. The reason of comparatively more number during rainy season may be due to high prey availability. Kushlan (1976) also reported similar tendency of some wading birds to aggregate at sites of high prey availability in favourable season. It can be stated that the species would be expected to be more packed as environmental variation decreases, resulting in monophasia (May and MacArthur, 1972).

Data presented in Figure 1 shows that population of the Black ibis was maximum during the rainy seasons of 2003 to 2005 while it was comparatively low in the rainy season of 2006 due to low rainfall in this year. The population of this bird was medium during the summer seasons and low during the winter of 2003 to 2006 . It may be due to low availability of food during these seasons.

Graphical presentation of data in Figure 2 depicts that the Juveniles numbers was more during post rainy months and pre winter months as the bird preferentially breeds during February to July i.e. pre monsoon season in this arid zone area.

Data of Figure 3 indicates that there is direct relationship between rainfall and the number of population of the Black ibis because good rainfall results in the availability of insects as food to the bird. However, low rainfall during 2006 could not improve the number of birds in the rainy season of this year. The diet of the Black ibis suggests the bird is largely a generalist, including, macro-invertebrates, and human garbage e.g. food scrapes etc. Similar observations have been made in Sacred ibis also (Clark, 1979; Kopij et al., 1996; Clergeau and Yesou, 2006; Williams and Ward, 2006). The generalist nature of the Black ibis in diet decides its population in different microhabitats in different seasons.

Data of Figure 4 show that there were some correlations between the availability of food in the rural and urban area of the study area and the population of the Black ibis. The number of ibis was comparatively more in rural area during winter and rainy seasons as the bird rends to feed in the sand 
K.C. Soni, A.N. Sharma and V.C. Soni / Our Nature (2009) 7: 193-202

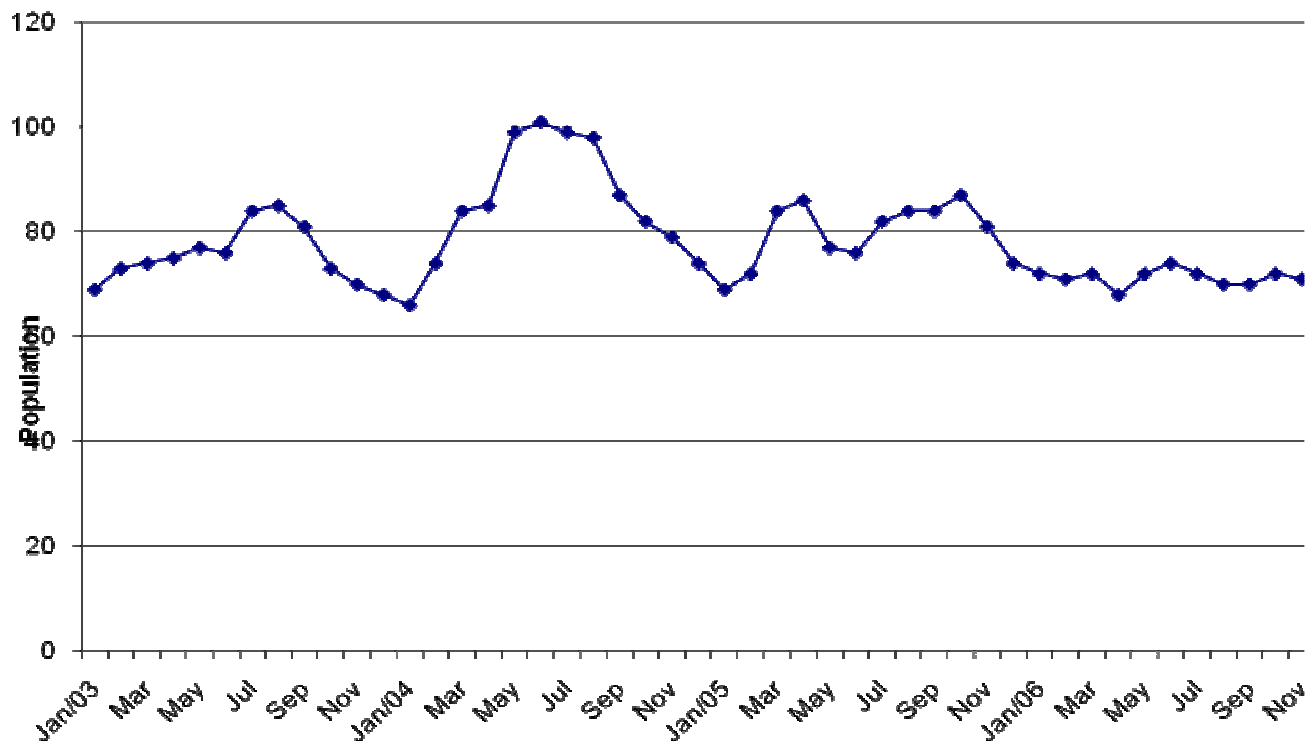

Figure 1. Monthlywise population trend of the Black Ibis from January 2003 to December 2006

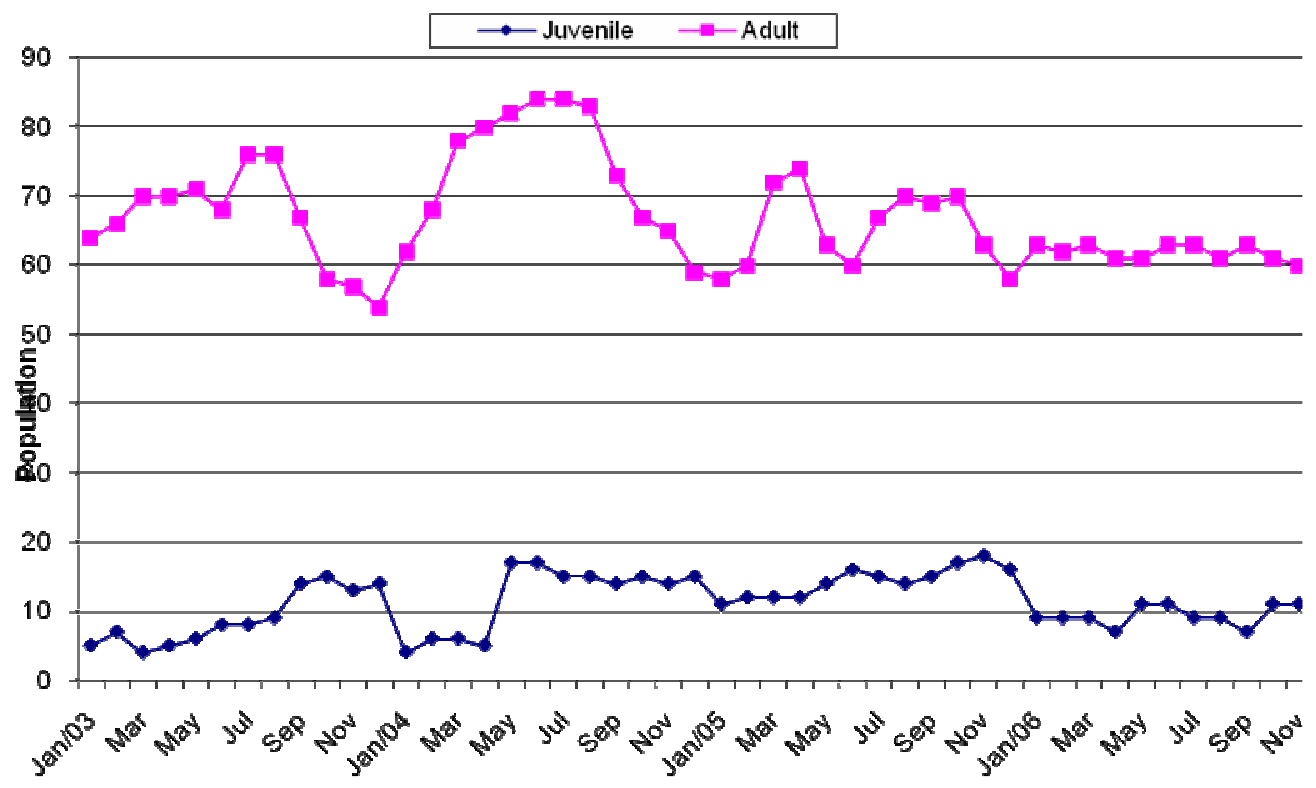

Figure 2. Monthwise population trend of Juvenile and adult Ibis from January 2003 to December 2006. 


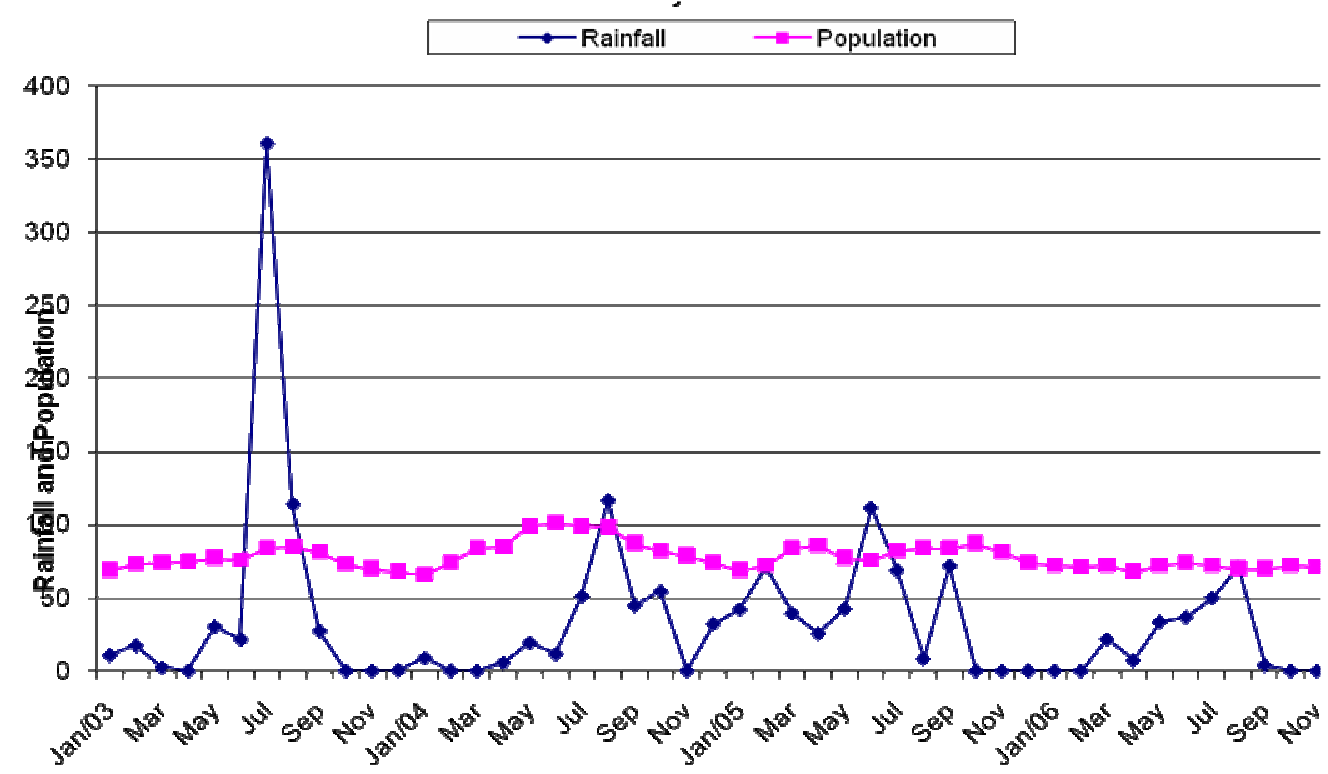

Figure 3. Graph showing correlation between rainfall and population of Black Ibis from January 2003 to December 2006

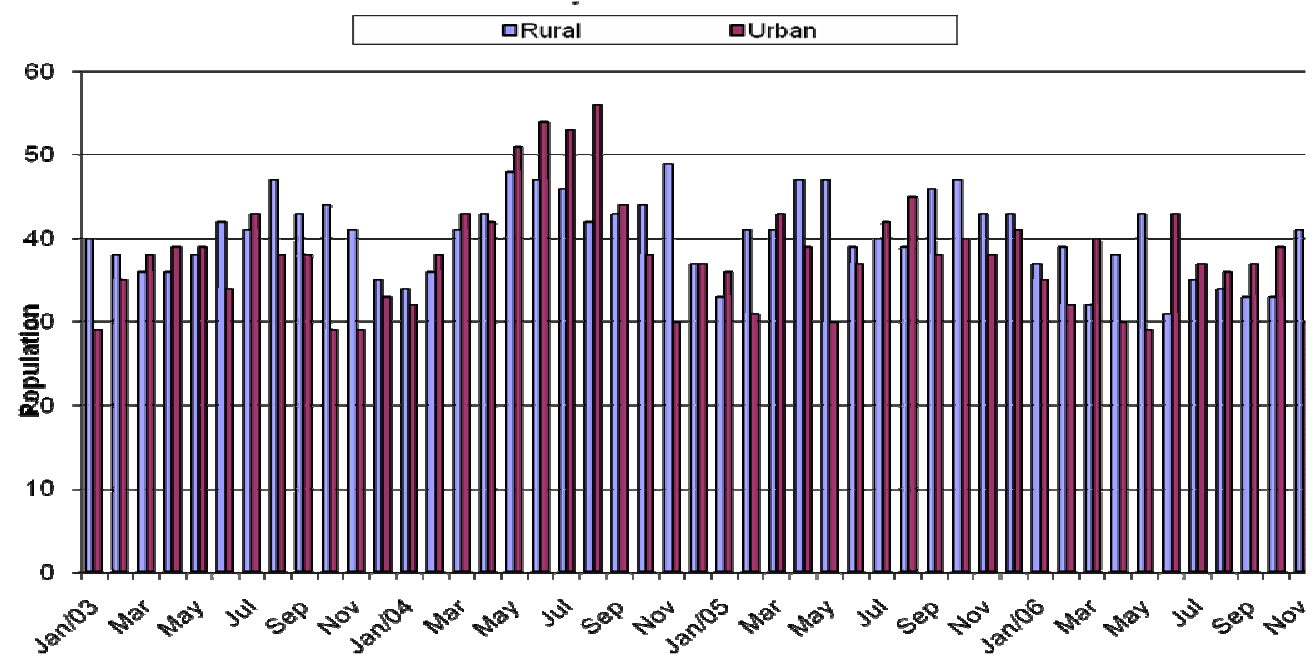

Figure 4. Monthwise population of the Ibis in rural and urban roost sites from January 2003 to December 2006.

dunes, grazing fields and agriculture fields in these seasons. In summer, the bird used to confine to the waste water bodies, Municipal garbage dumping stations in the nearby area of the city i.e. the urban area. The flock size of the Black ibis varies significantly with seasons. Similar correlation is also reported in Wooly necked 
K.C. Soni, A.N. Sharma and V.C. Soni / Our Nature (2009) 7: 193-202
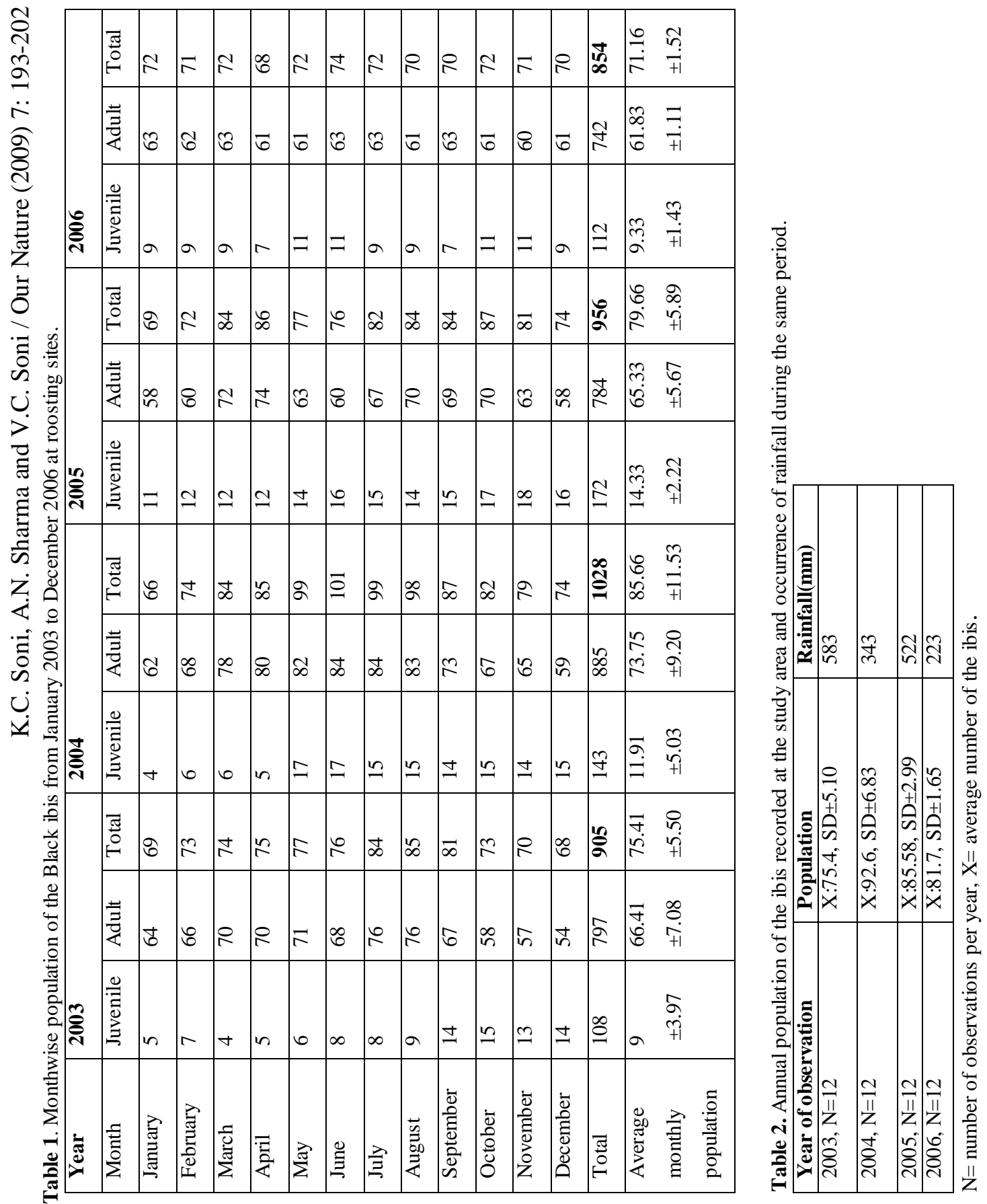
K.C. Soni, A.N. Sharma and V.C. Soni / Our Nature (2009) 7: 193-202

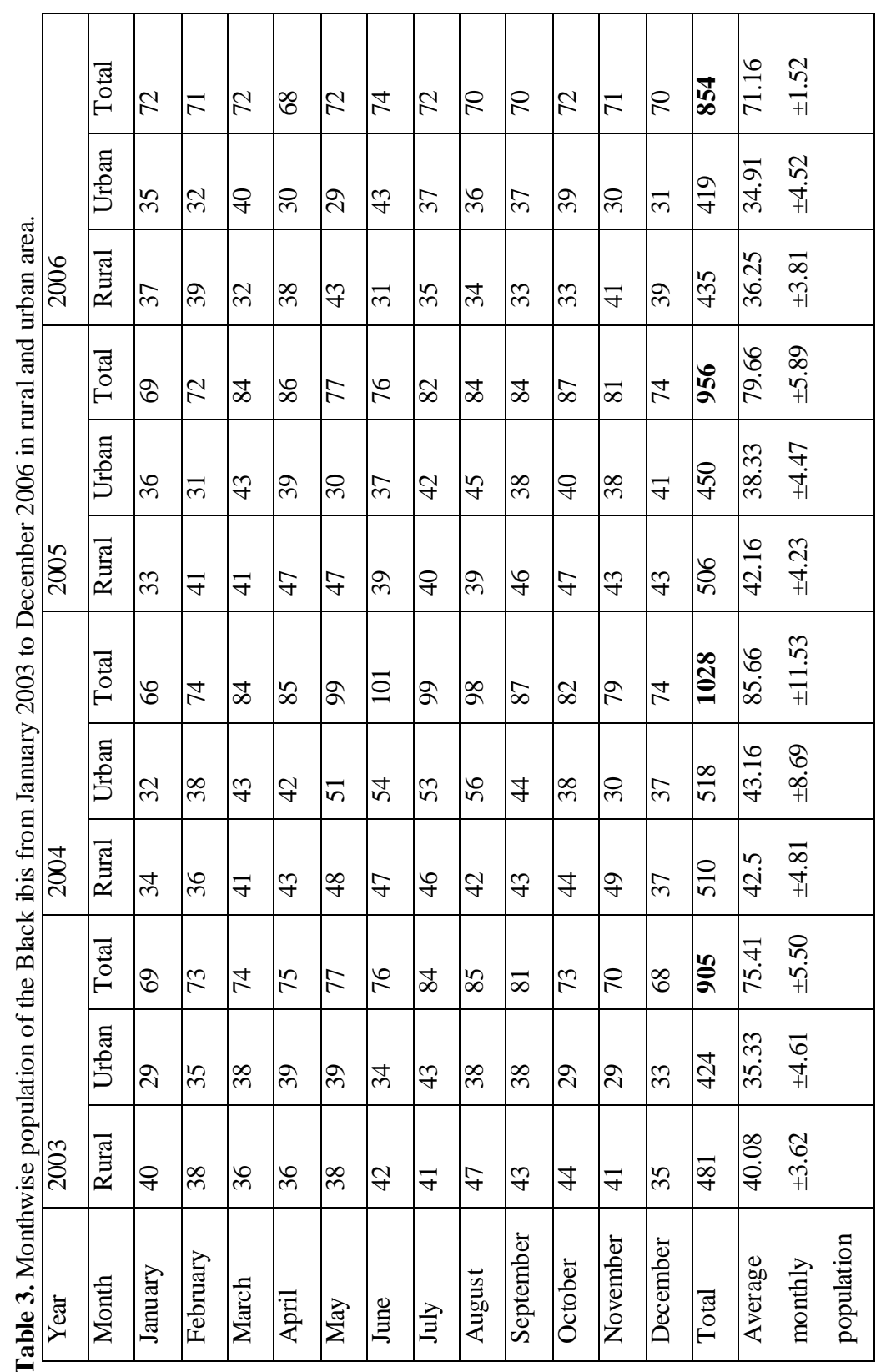


storks and Black headed ibis (Gopisundar, 2006).

The ability to exploit diverse feeding grounds enables the ibis to traverse both natural and man-made microhabitats. The scattered form of flocking during a normal rainfall year would allow the birds to forage in a variety of grounds, such as grazing field, agricultural farm houses and waste water bodies. An exact opposite situation occurs in the drought period. A phenomenon of the normal rainfall results in unlimited food supply, which leads to provincial emigration. However, lower rainfall restricts the useable foraging grounds, leading to the utility of limited resources, such as municipal garbage dumping station, waste water bodies, sand dunes, and animal dead bodies dumping station in rural area. That is why higher numbers of individuals prefers roosts in close proximity of feeding sites in the rural area. Even distribution of the birds supports this hypothesis that aggregation or dispersion is related to the availability of food resources and species would be expected to be more packed as environmental variation decreases, resulting in monophasia (May and MacArthur, 1972). Thus conclusion can be drawn that the dispersal of the ibis depends upon climatic conditions affecting food availability.

As breeding virtually ceases in winters, solitary breeding pairs tend to aggregate at communal roosts with their offspring's, which increases the strength of flock size. Stead (1932) recorded aggregation of the Australian harrier at certain roost sites just after the breeding season. This behaviour plays a potential role in the learning and social structure for the juveniles. They can follow the search and exploitation techniques of the adults during the period of potential limited resources in the shorter days of winter.

Post winter is a beginning of the breeding season for the majority of the avifaunal species all over the world. Besides heat regulation and its antipredation mechanism, a communal roost influences pair formation and pair bonding for the following breeding season. Observations by Gurr (1968) on the courtship behaviour of the Australian harrier on the roost supports the probable fact of communal roosting provides better mate selection and flow of stronger genes in future generations.

During good rainfall years, insect fauna and aquatic habitat flourish well. Apparently such situations encourage breeding dispersion during the pre and post winter periods, and with the normal bumps and busts the recruitment of young ibises at communal roosts during the winter. And finally, by and large conservative practices, religious attitude of multimillionaire people of the area and biodiversity of the Rajasthan state supports continuance of a substantive number of the ibis in both its urban and rural areas with periodically internal variations depending on climatic changes, food availability, and breeding strategies.

\section{Acknowledgements}

I am highly thankful to UGC, CRO, Bhopal for providing financial assistance for this work in the form of minor research project and to Prof. P.C. Frederick, Dr. K.L. Bildstein and Dr. M.C. Coulter (SIS Group) for providing valuable literature and guidance.

\section{References}

Ali, S. and S.D. Ripley 1983. Handbook of the birds of India and Pakistan. Oxford University Press, Bombay. 
Bull, E.L. 1981. Indirect estimate at abundance of birds. In Estimat in numbers of terrestrial birds (Eds. C.J. Ralph and J.M. Scott). Studies in Avian Biology 6: 76-80.

Chavda, P.B. 1988. Behavioural and ecological study of the Indian Black Ibis Pseudibis papillosa (Temminck) at Junagadh. Saurashtra University, Rajkot, India. (M. Phil. dissertation)

Clark, R.A. 1979. The food of the Sacred ibis at Pretoria, Transvaal. Ostrich 50: 104-111.

Clergeau, P. and P. Yesou 2006. Behavioural plasticity and numerous potential sources of introduction for the Sacred ibis: causes of concern in Western Europe. Biol. Invasions. 8: 1381-1388.

Conant, S., M.S. Collins and C.J. Ralph 1981. Effects of observers using different methods on the total population estimates of two resident island birds. Stud. Avian Biol. 6: 377-381.

Davis, D.E. 1982. Handbook of Census methods for terrestrial vertebrates. CRC Press, Inc. Boca Raton, Florida. pp. 93-103.

Dawson, D.G. 1981. Counting birds for a relative measure (index) of density. In Estimating numbers of terrestrial birds (Eds. C.J. Ralph and J.M. Scott). Studies in Avian Biology 6: 12-16.

Gadgil, M. and S. Ali 1975. Communal roosting habits of Indian birds. J. Bomb. Nat. Hist. Soc. 72(3): 716-727.

Gopisundar, K.S. 2006. Flock size, density and habitat selection of four large waterbirds species in an agricultural landscape in Uttar Pradesh, India: Implications for management. 29(3): 365-374.

Gurr, L. 1968. Communal roosting behaviour of the Australian Harrier Circus approximans in New Zealand. Waterbirds 110: 332-337.

Koen, J.H. 1988. A census technique for at romontone forest bird communities. Suid-Afrikaanse Bosboutydskrit-nr. 145: 39-41.

Kopij, G., O.B. Kok and Z.N. Roos 1996. Food of Sacred ibis Threskiornis aethiopicus nestlings in the Free State province, South Africa. Ostrich 67: 138-143.

Kushlan, J.A. 1976. Feeding rhythm in nestling white Ibis. Wilson Bull. 88: 656-658.

Lathigara, R. 1989. Behavioural and ecological studies on population census, roosting, foraging, feeding and breeding of the Indian Black Ibis at Jamnagar, India. Saurastra Univ., Rajkot, India. (M.Sc. Thesis)

May, R.M. and R.H. MacArthur 1972. Niche overlap as a function of environmental variability. In Proceedings of the national Academy of Sciences of the U.S. 69p.

Pyke, G.H. 1986. A preliminary analysis of bird counts made by N.S.W. Field Ornithologist' Club. Aust. Birds 20: 33-39.

Pyke, G.H. and H.F. Recher 1984. Censusing Australian birds: A summary of procedures and a scheme for standardization of data presentation and storage. In Methods of censusing birds in Australia (Ed. S.J.J.R. Davis). Dept. of Conservation and Environment, Perth, W. Aust.

Pyke, G.H. and H.F. Recher 1985. Estimated forest bird densities by variable distance point counts. Aus. Wildl. Res. 120: 307-319.

Ralf, C.J. and J.M. Scott 1981. Estimating the numbers of terrestrial birds. Stud. Avian Biol. No. 6. Cooper Ornithological Society, Lawrence, Kansas.

Robbins, C.S. 1981. Effect of time of day on bird activity. Stud. Avian Biol. 6: 275-286.

Salimkumar, C. 1982. Ecology and behaviour of the Indian Black Ibis, Pseudibis papillosa (Temminck) around Saurashtra University campus: an aerial study. Saurashtra Univ., Rajkot, India. (M.Sc. Thesis)

Sheshukumar, Y. 1984. Feeding ecology of the Indian Black Ibis, Pseudibis papillosa (Temminck) in and around Saurastra University campus, Saurastra Univ., Rajkot, India. (M.Sc. Thesis)

Skirvin, A.A. 1981. Effect of time of day and time of season on the number of observations and density estimates of breeding birds. Stud. Avian Biol. 6: 271-274.

Soni, K.C. 2008. Study on the population, foraging, roosting and breeding activities of the Black ibis/Red napped ibis (Pseudibis papillosa) inhabiting the arid zone of Rajasthan. M.D.S. University, Ajmer, Rajasthan, India. (Ph.D. Thesis)

Stead, E.G. 1932. Life histories of New Zealand birds. London (Search)

Sykes, W.P. 1983. Recent population trend of the Snail Kite in Florida and its relationship to water levels. J. Field Ornithol. 54(3): 237-246.

Verner, J. 1985. Assessment of counting techniques. Current Ornithol. 2: 247-302.

Ward, P. and A. Zahavi 1973. The importance of certain assemblages of birds as information-centres' for food-finding. Waterbirds 115: 517-534.

Williams, A.J. and V.L. Ward 2006. Sacred ibis and grey heron predation of cape cormorant eggs and chicks; and a review of ciconiiforme birds as seabird predators. Waterbirds 29: 321-327. 